\title{
CROSS SECTIONS OF LOWER ORDOVICIAN CARBONATE DEPOSITIONAL LITHOFACIES AND MISSISSIPPI VALLEY-TYPE ZINC- AND IRON-SULFIDE MINERALIZATION IN THE CAULFIELD DISTRICT, EAST-CENTRAL PART OF HARRISON $1^{\circ} \times 2^{\circ}$ QUADRANGLE, MISSOURI AND ARKANSAS
}

By

\author{
Timothy S. Hayes ${ }^{1}$, James R. Palmer ${ }^{2}$, and Gary Krizanich ${ }^{1}$
}

\section{FOLIO NOTE}

This report is part of a folio of maps of the Harrison $1^{\circ} \times 2^{\circ}$ quadrangle, Missouri and Arkansas, prepared under the Conterminous United States Mineral Assessment Program (CUSMAP). Other publications in this folio to date include U.S. Geological Survey Miscellaneous Field Studies Maps MF-1994-A and B (Erickson and others, 1988; McCafferty and others, 1989). Additional maps showing various geologic aspects of the Harrison quadrangle will be published as U.S. Geological Survey maps bearing this same serial number with different letter suffixes (MF-1994-D-E, etc.).

\section{INTRODUCTION}

As part of the Harrison $1^{\circ} \times 2^{\circ}$ CUSMAP study, we examined eight drill cores from the Caulfield district (see index map) in south-central Missouri. This report presents the results of the core study and cross sections and correlation diagrams compiled from the core data (cross sections $A-A^{\prime}$ and $B^{-} B^{\circ}$ and correlation diagrams $A-A^{\circ}$ and $B-B^{\circ}$ ).

\section{PURPOSE}

The purpose of this study was to identify geologic controls on zinc deposits in the Lower Ordovician

\footnotetext{
${ }^{1}$ U.S. Geological Survey

${ }^{2}$ Missouri Division of Geology and Land Survey
}

dolostone of the Caulfield district to better assess the economic potential of existing deposits and to aid in exploration for undiscovered deposits. Also, we needed to determine what rock features were important to recognize when logging cores of Lower Ordovician rocks for additional CUSMAP studies. Many core holes penetrate the Lower Ordovician (Canadian Series) rocks in southern Missouri and northern Arkansas. Lower Ordovician rocks do not host any known large-tonnage zinc deposits in southern Missouri or northern Arkansas, but they must be considered prospective host rocks, because the large districts of central and eastern Tennessee are in Lower Ordovician carbonate rocks that correlate with the Lower Ordovician rocks in southern Missouri and northern Arkansas (Kyle, 1976; Crawford and Hoagland, 1968).

We specifically studied the depositional lithofacies of the rocks in the eight cores to determine if there were preferentially mineralized lithofacies or arrangements of lithofacies. Such relations have been documented from large districts such as southeast Missouri (Snyder and Gerdemann, 1968; Gerdemann and Myers, 1972) and Pine Point, Canada (Rhodes and others, 1984; Skall, 1975). Whether or not lithofacies and mineralization were related, the lithofacies served as the basis of detailed stratigraphic correlation from core to core, and detailed correlation was prerequisite to recognizing any structural geologic controls on mineralization. Existing information suggested that detailed correlation within the upper part of the Canadian Series (Lower Ordovician) rocks was not possible, because stratigraphic sequences were 
believed to be highly variable over short distances. Earlier correlations were based mainly on insoluble residue studies of Grohskopf and McCracken (1949).

We questioned whether there was any field evidence to link the Caulfield district to a larger, regional mineralized system of the Ozark region proposed by Leach and Rowan (1986). If the Caulfield deposits are part of a larger system, then these small deposits might provide evidence on the genesis of the whole system, eventually leading to a more effective mineral-potential assessment of the region.

We tried to supplement results from previous studies of the Alice mine, largest zinc producer of the Caulfield district. Previous work includes Needham and Kreamalmyer (1947) and Kidwell (1945; 1946). Needham and Kreamalmyer (1947) reported the results of U.S. Bureau of Mines drilling and geophysical exploration, demonstrating that a reserve of low-grade sphalerite-mineralized rock exists beneath the open pit at the Alice mine. Kidwell (1946) reported the mineral paragenesis at the Alice mine. Kidwell (1945) had earlier described the geology at the Alice mine and discussed controls of the deposit, concluding that it is hosted by a zone of bedding collapse that is a north-south elongate oval in plan, with unknown vertical extent and plunge.

\section{METHODS}

For this study we logged eight drill cores at a scale of $1: 120$, and briefly examined the Alice mine open pit (see index map). The cores are part of a larger collection of cores from the Caulfield district donated to the Missouri Division of Geology and Land Survey Core Library by the Kerr-McGee Corporation.

The eight cores studied are aligned along strike, according to regional structure contours from Bohm (1981) and from C.M. Seeger and E.E. Glick (unpub. data, 1987). Four of these cores were used to make a cross section through the middle of the open pit at the Alice mine (cross section and correlation diagram $A-A^{\prime}$ ). The other four cores (cross section and correlation diagram B-B ${ }^{\circ}$ ) were used to make a cross section at the Taylor prospect, which consists of four drillholes about $6 \mathrm{mi}$ east-southeast of the Alice mine. The Alice mine cores were chosen to provide data indicating possible bedding collapse in the mine area (Kidwell, 1945), whereas the Taylor prospect cores provide data used to correlate stratigraphy across the area and also to provide data indicating possible structural disturbance of the gentle, regional homocline at that prospect. To construct the cross sections, the holes were projected along local dips, which were measured in outcrops $300 \mathrm{ft}$ east of the pit at the Alice mine, to the lines of section. The local dip at the Alice mine, $2.5^{\circ}$ to the south-southwest, is significantly greater than the regional dip (Bohm, 1981), which is less than $0.5^{\circ}$. Using the steeper dip of the Alice mine area to project Taylor prospect cores to the plane of section B-B' has resulted, because of the location of core holes, in the appearance of a very gentle syncline in the vicinity of core hole C-101. That syncline is probably a method artifact, and bedding at the Taylor prospect is probably at an attitude very near the less than $0.5^{\circ}$ regional dip. However, the apparent offset between holes C-101 and C-104 is too great to be accounted for by a reasonable change in dip, and so we infer that the offset is due to a fault.

All results reported here are from field examination of cores and hand specimens by binocular microscope. Descriptions are from slabbed and finely ground (1,000 grit-less than micron sized) rock samples, many of which were also etched for 1 minute in 1.5 percent hydrochloric acid solution to distinguish calcite from dolomite, then stained in alizarin red-S and potassium ferricyanide solution (Dickson, 1966) to distinguish iron contents of various carbonate generations. The only mineral not field identified by macroscopic physical properties (including the methods above), but listed here, is hemimorphite. It was identified by X-ray diffraction.

Additional study of Caulfield district and Alice mine samples by petrographic, geochemical, and perhaps isotopic methods is desirable, because hydrothermal dolomite identified during this brief field study demonstrates that the Caulfield zinc district is part of a regional hydrothermal system of Mississippi Valley-type $\mathrm{Pb}-\mathrm{Zn}$ deposits. The Alice mine, because of its simplicity, is an outstanding place to learn more about Mississippi Valley-type sulfide deposits.

\section{ACKNOWLEDGMENTS}

We thank Mr. Douglas Sasseen of Bakersfield, Missouri, for granting access to the Alice mine. Drill cores alone would have left us with a very incomplete view of the mineralization there. We also thank KerrMcGee Corporation for their donation of exploration cores to the Missouri Division of Geology and Land Survey Core Library. We thank Mr. Hairl Dayton and Mr. Jerry Plake of the Division of Geology and Land Survey for their assistance in locating and moving cores within the core library. 


\section{CARBONATE SEDIMENTATION}

Carbonate rocks and their chert-replaced equivalents are described and discussed here using the carbonate rock classification of Dunham (1960). Carbonate crystal-size and certain textural nomenclature is according to Friedman (1965). Detrital particle-size nomenclature is that of Wentworth (1922). Bed thickness nomenclature is according to Ingram (1954). And certain bedforms are described according to Reineck and Singh (1975).

The Lower Ordovician Jefferson City and Cotter Dolomites, the host rocks to mineralization in the Caulfield district, are a cyclic sequence of dolostone beds that was deposited in shallow, peritidal environments in a probably semiarid climate. Sedimentation cycles within the Cotter Dolomite in the Caulfield district were logged by moving up-section through a single, full cycle and describing each lithofacies rock assemblage. In this report, we have defined five lithofacies assemblages (a-e) within the Cotter Dolomite. Rock types, primary sedimentary structures, bed thicknesses, colors, textures, and other features are described for each of the five lithofacies assemblages that make up an idealized full cycle. All of the carbonate rocks described are dolostone, though they were probably deposited as calcium carbonate. Explanation of the regional dolomitization is beyond the scope of this report. Depositional fabrics are generally well preserved despite dolomitization; only local zones have depositional textures obliterated by later processes. Cycles are described in the following paragraphs and are shown on correlation diagrams $\mathrm{A}-\mathrm{A}^{\prime}$ and $\mathrm{B}^{-\mathrm{B}^{\prime} \text {. }}$

\section{LITHOFACIES ASSEMBLAGE "a"}

Lithofacies "a" (see correlation diagrams A-A"

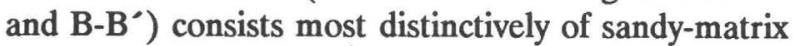
sedimentary breccia that commonly overlies desiccation-cracked dolostone surfaces. Downward wedging desiccation cracks within the underlying dolomudstone or stromatolitic boundstone are filled with very fine to medium-grain-size quartz sand. This sandy lithology atop cracked surfaces may grade upward within a few centimeters into clast-supported, angular-clast sedimentary breccia with a sandy matrix. Below the mudcracked surface(s) in cores are thin sandstone dikes that may or may not be connected to an overlying lithofacies-a sandy bed. Origin of the sandstone dikes is believed to be related to early desiccation rather than to any later diapiric or tectonic instability, because dike-rich layers are areally persistent. Upward or laterally, some lithofacies "a" beds grade to intraclast-rich, conglomeratic sandstone containing subrounded dolomudstone clasts. Some lithofacies "a" beds grade eventually to small-scale trough cross-stratified sandstone containing scattered dolomudstone intraclasts. These two rock types are the most distinctive types of sandstone within the cycles. Where lithofacies "a" is intraclast-bearing sandstone, there may be no underlying mudcracked surface, and the base of the lithofacies, and the cycle base as we have interpreted it, is an erosionally scoured surface with local relief of a few centimeters or less. The cross sections and correlation diagrams show that relief over larger distances on these scoured surfaces is no more than a few feet per mile, yet we know from experience elsewhere in the region that this type of scoured surface has frequently been considered a gentle angular unconformity representing a significant erosional gap in the sedimentary record. Lithofacies " $a$ " is generally thin, usually no more than $60 \mathrm{~cm}$ thick and commonly only around $10 \mathrm{~cm}$. These intervals commonly have a very sharp base, which is either a scoured surface or a desiccation-cracked surface, and a top that grades upward into rocks of lithofacies assemblage "b," where micron grain size dolomite increases and quartz sand content decreases. Colors of unweathered rock are dependent on the amount of quartz sand relative to dolomite, varying from nearly white quartz sandstone to brown and dark-brown dolostone containing sand-filled cracks or breccia matrix.

\section{LITHOFACIES ASSEMBLAGE "b"}

Lithofacies "b" occurs above lithofacies "a" (correlation diagram A-A and B-B') and is generally the thickest interval of a sedimentation cycle. This lithofacies constitutes the bulk of the Cotter Dolomite. These rocks, where they were not bioturbated, are very thinly bedded dolomudstone and pelloidal wackestone that are wavy laminated. Very fine grained quartz sandstone, siltstone, or dolomitic grainstone occur as thin or very thin, connected lenses within the dolomudstone. Dolomite crystal sizes vary locally due to recrystallization, but generally the crystal size is micron to decimicron size. Bedding is generally disrupted. Where beds have been disrupted, the rock is either massive and homogeneous or it has an intricate pattern of gray "tracks" marked by intergranular, very finely crystalline pyrite and organic matter. Most of the tracks are probably burrows. 
Dolomudstone, packstone, and grainstone are surprisingly porous for such fine-grained rocks. Water brushed onto a slabbed core is absorbed within 15-20 seconds. These rocks are thus known locally as "cottonrock" and were logged as such as a field abbreviation. They recur frequently throughout the entire drilled section, which led us to abbreviate their description to "A," and that led eventually to the designation of the " $\mathrm{A}$ " rock marker bed (cross sections and correlation diagrams $A-A^{\prime}$ and $B-B^{\prime}$ ). Centimeter-scale graded beds are present, but not common in lithofacies "b." Lithofacies "b" rocks rarely have crudely developed cryptalgal lamination. They sometimes have interbedded or intermixed dark siliciclastic shale. They frequently contain widely scattered quartz crystal masses, $1-10 \mathrm{~cm}$ in size and very irregularly shaped, which are one of the identifying insoluble residues of the Cotter Dolomite (Grohskopf and McCracken, 1949). In the Caulfield district, these quartz masses are commonly geodes containing terminated colorless quartz crystals growing inward from a shell of blue-gray, layered chalcedony. Origin of the geodes is unknown at this time but they could be psuedomorphs of sulfate nodules (Folk and Pittman, 1971; Milliken, 1979). Lithofacies "b" varies in thickness from 3 to $5 \mathrm{~m}$, is gradational with sandy rocks below, and is commonly in erosional contact with grainstones above. Locally, the top of lithofacies "b" sequence is gradational into fine-crystalline, burrowed, pelloidal packstone and then into pelloidal grainstone assigned to lithofacies assemblage "c." Colors within lithofacies "b" are highly variable but commonly include medium and dark gray and brown. In the Cotter and Jefferson City Dolomites, browner color indicates more organic matter.

\section{LITHOFACIES ASSEMBLAGE "c"}

This lithofacies includes a variety of types of grainstone, any of which locally contain minor quartz sand (correlation diagrams $A-A^{\prime}$ and $B-B^{\circ}$ ). In cycles where the lithofacies " $b$ " rocks are topped by a scoured surface, lithofacies "c" is generally $30 \mathrm{~cm}$ thick or less, consisting of poorly sorted conglomeratic lithoclast-pelloid grainstone that grades upward to packstone and thrombolitic microbial boundstone. Ooidal grainstone also occurs. Where lithofacies " $b$ " rocks grade upward into a grainstone interval, lithofacies "c" may be as much as about $2 \mathrm{~m}$ thick consisting mostly of well-sorted, pelloidal or ooidal grainstone. Features within well-sorted grainstone are commonly somewhat cryptic owing to recrystallization. The rocks are actually equigranular, fine-crystalline, xenotopic dolostone, but binocular examination of sawed and finely ground surfaces reveals "ghosts" of a well-rounded allochem, one allochem per dolomite spar crystal. Some recrystallized chert contains preserved depositional textures, such as ooids or pelloids. Thicker "c" intervals grade upward into thrombolitic microbial boundstone. Color of "c" interval rocks varies considerably but medium brown is common.

\section{LITHOFACIES ASSEMBLAGE "d"}

Lithofacies " $\mathrm{d}$ " is a sequence of microbial boundstone rock types containing lesser amounts of pelloidal or ooidal packstone and grainstone (correlation diagrams $\mathrm{A}-\mathrm{A}^{\circ}$ and $\mathrm{B}^{-} \mathrm{B}^{\circ}$ ). The sequence begins with thrombolitic boundstone, grades upward into burrowed pelloidal grainstone, then into hemispheroidal stromatolite boundstone, and finally into cryptalgalaminites containing local, low-relief hemispheroids that are either isolated or laterally linked. This subcycle within the thicker cycles may then repeat itself. These boundstone subcycles are labelled lithofacies assemblage "d."

Recrystallization may make distinction between burrowed grainstone and thrombolitic boundstone difficult, but this part of the cycle is nonetheless easily identifiable by its clotted or mottled colors and grain sizes. Even where coarsely recrystallized, lithofacies "d" can be identified by the upward varying geometry of vugs: irregular, large, and connected in thrombolitic and burrowed rock; crescentic and concave downward in hemispheroidal boundstone; and horizontal and planar in cryptalgalaminite. Thrombolitic boundstone and burrowed pelloidal grainstone are a thick-bedded to very thick bedded division of the Lower Ordovician cycles, commonly 0.6-1.5 m thick. Hemispheroidal and planar boundstone may be either thick or thin bedded. Boundstone divisions of cycles are generally about $2 \mathrm{~m}$ thick. Colors vary dramatically within the boundstone lithofacies. Thrombolitic boundstone and ooidal grainstone, in particular, may be very dark brown. Burrowed pelloidal grainstone is commonly mottled light gray and tan. Hemispheroidal boundstone and cryptalgalaminites are mostly light brown, tan, and pale greenish gray, but may be any shade of gray, brown, or drab green. Dolomite crystal sizes also vary dramatically mostly because of recrystallization. Maximum crystal sizes are medium crystalline but crystals are as small as micron size within any part of the boundstone subcycle. Porphyrotopic texture is common. 


\section{LITHOFACIES ASSEMBLAGE "e"}

The uppermost interval of the Lower Ordovician cycles is a sequence of beds dominated by thin- and very thin bedded dolomudstone (correlation diagrams A-A $A^{\prime}$ and B-B') similar to lithofacies "b." It differs from lithofacies " $b$ " in having only infrequent burrowing, relatively frequent centimeter-scale graded beds, and sparse desiccation-cracked bedding surfaces. Lithofacies "e" rocks also have very thin, flaser- and lenticular-bedded, decimicron-crystalline, micritic beds and rare shale interbeds; relatively abundant quartz masses; and sparse tabular-shaped, coarse crystals of quartz, pseudomorphic after anhydrite (or as $1 \mathrm{~mm} \mathrm{x}$ $2 \mathrm{~mm}$, hollow, tabular molds after anhydrite). Cryptalgal lamination is also locally present, notably including a few occurrences of the scallop texture described by Logan and others (1974).

The distinguishing features of lithofacies "e" rocks are sparsely distributed so that the " $\mathrm{b}$ " and "e" lithofacies are, at places, hard to distinguish. Centimeter-scale graded beds and desiccation cracked surfaces and the general absence of burrowing are the major criteria identifying lithofacies "e." Spatial relation to other assemblages is also helpful: lithofacies " $d$ " commonly grades up to lithofacies "e", whereas lithofacies "b" grades up from the usually distinctive lithofacies "a."

Lithofacies "e" rocks are everywhere topped by a sharp contact. At places, the overlying rocks are sandy-matrix sedimentary breccia or lithoclast-bearing quartz sandstone of lithofacies "a." At other places the overlying rocks are lithofacies "c" grainstone beneath a boundstone subcycle. The thickness of lithofacies "e" interval rocks is generally less than $2 \mathrm{~m}$. Colors within lithofacies " $\mathrm{e}$ " are commonly lighter than other lithofacies colors. Cream-colored dolostone made up of micron- to decimicron-size crystals is most common, though darker colors are also present.

Though these generalized descriptions of lithofacies a-e may give the impression that individual cycles are also lightening-upward color cycles, color variation is more irregularly distributed than the lithofacies. Several lithofacies cycles may combine to form a single lightening-upward color cycle.

\section{INTERPRETIVE DEPOSITIONAL MODEL}

Lithofacies assemblage cycles described from the Caulfield district are shallowing-upward sequences and are comparable with shallowing-upward sequences described by James (1979). However, Lower Ordovician cycles described in this report are unusually muddy. They differ in this way and in other details from shallowing-upward sequences that have been described from other ancient or modern carbonate depositional systems.

Quartz sand recurrence in the lithofacies cycles within the Canadian Series dolostone is best explained as the product of an eolian sand supply that dominated only when the broad, shallow shelf was cyclically at its most sediment-choked, shallowest state. Quartz sand was then redistributed and redeposited through several depositional environments in the next transgressive-regressive episode. We do not interpret the sandy sediment as unreworked eolian deposits.

The basal lithofacies assemblage " $\mathrm{a}$ " is interpreted as a transgressive lag deposit formed during or shortly after an abrupt sea-level rise had flooded the shelf. Transgression buried the underlying cycle and locally ripped up, eroded, and sorted the earlier sediment. Less eroded places preserve desiccation-cracked surfaces and sandy-matrix sedimentary breccia, but more deeply eroded places have lithoclast-bearing sandstone.

Maximum relative sea-level stand of each cycle is recorded by lithofacies assemblage "b", which is interpreted as deposits of subtidal mudbanks and is comparable with the locally island-topped mudbanks of modern Florida Bay (Enos and Perkins, 1979). Like the bank lithology of modern Florida Bay, lithofacies "b" shows a maximum of burrowing. By analogy with modern Florida Bay, where subtidal lithology is muddier than at any other described modern shallow-water carbonate deposystem, the abundance of micrite in the interpreted subtidal rocks probably records the presence of either a sill or a wide wave-dampening platform to protect the mudbanks from high- energy wave action that would winnow out some of the lime mud. We do not know where the sill was, but we suspect that in the Lower Ordovician rocks, only deposits far away from the sill and the Caulfield district would record any depositional change from the cyclic peritidal deposits. We further speculate that only at or beyond the sill would it be likely to find a limestone-dolostone interface within the Lower Ordovician rocks. Limestone-dolostone interfaces are commonly found close to major Mississippi Valley-type deposits, and interface locations are commonly controlled by lithofacies permeability.

Gradational transitions upward from muddy to grainy carbonate are found in many peritidal, shallowing-upward sequences that have been described 
in the literature (Fischer, 1964; Laporte, 1967; Hagan and Logan, 1974; Hardie and Ginsburg, 1977; James, 1979; and Shinn, 1983). However, the Lower Ordovician cycles of the Caulfield district more commonly have a sharp contact between underlying mudstone and wackestone and overlying grainstone. We currently have no explanation for this difference, but we interpret the lithofacies " $c$ " grainstone interval of the cycles to be entirely subtidal, because we recognize a complete subtidal-intertidal transition in rocks of lithofacies " $\mathrm{d}$ " and "e" overlying the grainstone of lithofacies "c."

Lithofacies assemblage " $d$ " is interpreted to record a transition from shallow subtidal to intertidal sedimentation. This interpretation comes from analogy with at least four well-described modern stromatolite-depositing carbonate coastlines. These are (1) the Persian Gulf (Purser and Evans, 1973); (2) Shark Bay, Australia (Hagan and Logan, 1974; Logan and others, 1974); (3) Andros Island in the Bahamas (Hardie, 1977); and (4) Florida Bay (Enos and Perkins, 1979). At each of these places, the upward transition from pelloidal, ooidal, or skeletal grainstone into hemispheroidal boundstone and then into planar boundstone occurs over the range from subtidal to the base of the supratidal environment. The described analogues for grainstone vary from high-energy carbonate beaches and barriers to subtidal banks. For stromatolitic rocks, they vary from continuous, elongate coastline evaporitic flats to protected quietwater bays and island-fringing or small island-interior tidal flats. The upper part of lithofacies "b" varies from pelloidal grainstone (subtidal to intertidal) to hemispheroidal stromatolite boundstone (lower intertidal) and to planar stromatolite boundstone (upper intertidal). We interpret that the thrombolite boundstone is an entirely subtidal lithology overlain by the subtidal to intertidal grainstone sequence just described.

Lithofacies "e" is interpreted as the shallowest water deposit of the Lower Ordovician cycle and includes supratidal and shallow intertidal rocks from tidal-flat environments. Centimeter-scale graded beds were deposited during storms on tidal channel levees and in overbank ponds (Hardie and Ginsburg, 1977; Shinn, 1983). Scallop-textured laminites were deposited by tufted algal mats (Logan and others, 1974). The graded beds and laminites both represent supratidal environments. The presence of mudcracks and the general absence of burrowing support the supratidal interpretation, as does the local presence of tabular pseudomorphs or molds after anhydrite.
Sulfate mineral pseudomorphs are rare and minor. They are preserved, excluding the irregular quartz masses and geodes, in less than 1 percent of the section, and there they total nowhere more than 5 percent of the rock volume. The total volume of sulfate minerals, including quartz masses as speculative evaporite pseudomorphs, totals no more than 10 percent of the rock thickness, containing an average of no more than 10 volume percent total sulfates prior to replacement by quartz. Disseminated, very finely crystalline pyrite is found in every lithofacies assemblage in amounts averaging less than 1 volume percent. The pyrite indicates that, just prior to ore deposition, pyrite was a stable sulfur mineral throughout the host-rock sequence. Anhydrite was apparently not stable and was replaced or removed.

Thus, each complete lithofacies assemblage ("a""e") is interpreted as a single transgressive-regressive depositional cycle. The vertical sequences were produced by lateral migration of lithofacies on the paleoslope. Preserved rock thickness of each lithofacies assemblage is a measure (after compaction) of the vertical relief on the sloping bank over which that lithofacies was deposited. The vertical lithofacies sequence "b-e" resulted from lateral progradation of the entire sloping carbonate bank. Superposition of one lithofacies over another through the regressive part of the sequence (middle of lithofacies " $b$ " through lithofacies "e") indicates higher and more landward position on the paleoslope for the upsection lithofacies (Walther's Law; Walther, 1894). We thus model a carbonate bank or banks on which lime mudstone was being deposited and burrowed, offshore and downslope from a variety of types of grainstone which were offshore and downslope from a low-energy coastline. Coastline sediment was dominated by microbial binding. The nearshore subtidal, intertidal, and supratidal shoreline zone of the deposystem was the site of deposition of carbonate sediment that is, in nearly every respect, identical with modern stromatolitic tidal-flat depositional environments. Shallowing-upward sequences were deposited by lateral shoreline progradation and coalescence of islands and mudbanks similar to those of modern Florida Bay (Enos and Perkins, 1979). Sea-level adjustments due to either tectonism or glacial-eustatic change caused relatively abrupt deepening of waters across the shelf and caused shoreline transgression. Slow progradation and regression followed to produce each complete cycle. 
The most common variation in these cycles is a cut-off top where lithofacies "a" directly overlies lithofacies "b," "c," or "d" rocks (correlation diagrams $A-A^{\prime}$ and $B-B^{\prime}$ ). This type of truncated cycle is easily explained by submarine erosion during the transgressive episode marked by lithofacies "a".

Other variations in sequence also occur. A common lithofacies repeat sequence is "c-d-e-c-d-e" (correlation diagrams $\mathrm{A}-\mathrm{A}^{\prime}$ and $\mathrm{B}^{-\mathrm{B}^{\prime}}$ ). We do not fully understand this type of sequence. One possibility is that the grainstone (lithofacies " $c$ ") environment was channeled and the laterally shifting channels repeatedly deposited, in turn, lithofacies "c-d-e" during continuous subsidencè. Such channels would necessarily be mostly subtidal.

Other variations from the full "a-b-c-d-e" cycle (correlation diagrams $\mathrm{A}-\mathrm{A}^{\circ}$ and $\mathrm{B}-\mathrm{B}^{\circ}$ ) are generally explainable by analogy with modern Florida Bay (Enos and Perkins, 1979). There, some mudbanks toward the windward (west) side of the bay have very grainy coquina tops and have muddy slopes as much as $5 \mathrm{~m}$ high. As Florida Bay very gradually becomes shallower eastward over its "basement" of Pleistocene limestone, the mudbanks decrease in thickness. Because they are more protected than mudbanks to the west, the eastern mudbanks do not necessarily have any winnowed grainstone in the subtidal and intertidal zones. Eventual progradation and island coalescence is thus expected to make a single shallowing-upward sequence that thickens westward. The package can be expected to include a very irregular layer of skeletal grainstone that eventually wedges out eastward within the sequence. Similar pinch-outs of subtidal and intertidal lithofacies " $c$ " and lower " $\mathrm{d}$ " are shown on correlation diagrams A-A" and $\mathrm{B}-\mathrm{B}^{\prime}$, but they are fairly rare considering the 6 mi distance between the two cross sections and the numerous shallowing-upward sequences examined.

\section{CORRELATION}

Correlation diagrams $\mathrm{A}^{-\mathrm{A}^{-}}$and $\mathrm{B}-\mathrm{B}^{\circ}$ demonstrate that, with detailed core logging and closely spaced holes, correlation within the Lower Ordovician rocks is simple. Furthermore, correlation across the $6 \mathrm{mi}$ between the Alice mine and the Taylor prospect is straightforward. We conclude that correlation of these rocks over distances of $10-20 \mathrm{mi}$ is possible, and with an extensive program of detailed sample logging, it should be possible to confidently correlate and understand deposition throughout the Canadian Series all across southern Missouri using the currently existing coverage of cores and cuttings and insoluble residue samples from drill holes in the collection of the Missouri Division of Geology and Land Survey.

Correlation was first attempted using unique lithology marker beds that are locally cherty. However, the recognition of "a-b-c-d-e" cycles was a tremendous boon to correlation, and it was the correlation of drill holes, cycle for cycle, between unique lithology marker beds that has resulted in the bed-for-bed correlation demonstrated in cross sections $A-A^{-}$and $B-B^{-}$and correlation diagrams $A-A^{-}$and $B^{-} B^{\prime}$. The cherty marker beds further placed the Caulfield district host rocks quite firmly within the middle and lower parts of the Cotter Dolomite of the insoluble-residues stratigraphy of McCracken and McCracken (1964).

\section{POST-DEPOSITIONAL BRECCIA AND FRACTURING}

A result of this study is the discovery of a stratabound body of healed, coarsely crystalline breccia $300-400 \mathrm{ft}$ below the surface beneath the Alice mine and the Taylor prospect. The Alice mine's host rock, micron- to decimicron-crystalline, angulardolostone-clast, collapse-crackle-breccia, may have collapsed into this stratabound breccia body (cross section $A-A^{\prime}$ ). Thus, the Alice mine appears to occupy a collapse-breccia pipe connected to or rooted in the stratabound breccia.

\section{STRATABOUND BRECCIA}

Four of the drill holes studied intersected a body of breccia $65-100 \mathrm{ft}$ below the "A" rock marker bed, at elevations between 600 and $700 \mathrm{ft}$ above sea level. This breccia appears to be stratabound and mostly continuous between the Alice mine and the Taylor prospect. Because it is cut by veinlets of ore-stage minerals or has vugs containing ore-stage minerals, the brecciation and the recrystallization appear to be pre-ore. In drill holes C-3 and C-6 (cross section $A-A^{*}$ and correlation diagram $A-A^{*}$ ), the dip of bedding increases gradually toward this breccia, indicating a gravitational collapse of rocks into the stratabound breccia zone. Entering the stratabound breccia zone from above, the rocks grade from fractured micron-crystalline dolostone; to cracklebrecciated micron-crystalline dolostone, having as much as 20 percent fracture porosity; to decimicroncrystalline mosaic-brecciated and rehealed dolostone; and finally to rehealed mosaic- to rubble-brecciated, 
fine- to very coarse crystalline dolostone. Early replacement cherts preserve depositional textures and are found sporadically throughout the rock section as breccia fragments, and are not replaced or recrystallized within the stratabound breccia.

In most of its drilled intercepts, the stratabound breccia is a medium- to very coarse-crystalline, mostly rehealed, angular-clast, mosaic breccia having only minor open space. It is tan to light gray brown, and clasts vary from less than a millimeter to at least several centimeters. Because the core diameter is 3.5 $\mathrm{cm}$, it is difficult to document that larger clasts exist in the breccia, but it is likely that clasts as much as several tens of centimeters in size are included. The clasts are visible as coarse-crystalline, xenotopic to hypidotopic, light-colored, angular to subrounded dolostone fragments in a darker, grayish dolostone matrix. The matrix is generally slightly finer crystalline and has minor intercrystalline gray clay or pasty-white, finely porous chert. The matrix may be discernibly laminated, especially where there is abundant intercrystalline clay, with some draping of laminae over and around clasts. At places, the matrix grades to laminated, slightly dolomitic shale, almost certainly a former internal sediment. Most open space postdates the brecciation. Porosity is developed mainly as small, intercrystalline vugs occurring selectively within the breccia clasts. Very sparse larger vugs may have geopetal floors of tan, decimicron-crystalline dolomite and are the sites of other minor, late, hydrothermal-stage minerals. The only other sites of hydrothermal-stage minerals are veinlets that cut through clasts and matrix alike.

\section{ALICE MINE COLLAPSE BRECCIA}

In cross section $\mathrm{A}-\mathrm{A}^{-}$and correlation diagram $A-A^{*}$, the dips of bedding from measurements on dolostone blocks of several meters to tens of meters in size within the Alice open pit have been projected to the plane of section. As stated by Kidwell (1946, p. 8 ) and by Needham and Kreamalmyer (1947, fig. 2), bedding dips in various rotated blocks within the open pit are inwards toward the center, at angles of as much as $15^{\circ}$. Outside the pit, scattered outcrops dip homoclinally to the south-southwest at less than $3^{\circ}$, an observation corroborated by the lack of vertical disparity of features in projected drill holes in cross section $\mathrm{A}-\mathrm{A}^{\prime}$ and correlation diagram $\mathrm{A}-\mathrm{A}^{\prime}$. The Alice pit is only about $270 \mathrm{ft}$ in diameter and generally circular in plan, so the volume of rock having disturbed dip is very small. Cross section A-A' (including its trace of bed 2 according to Kidwell,
1945) shows that the Alice mine is centered on a bedding collapse. But projection of dips measured in the pit suggests only about $20-30 \mathrm{ft}$ of vertical subsidence at the pit center (cross section $\mathrm{A}-\mathrm{A}^{\circ}$ ), whereas Kidwell suggested more than $40 \mathrm{ft}$. Kidwell based his estimates on a chert marker bed, his bed 2, that he located in pit outcrops and in drill cuttings from churn-drill holes in and around the pit. Our core logging and work in the pit shows that chert is found sporadically through the section and is discontinuous laterally along bedding. We believe that Kidwell was not picking bed 2 in all drill holes, and that our estimate of 20 to (no more than) $30 \mathrm{ft}$ of vertical subsidence over the $150 \mathrm{ft}$ radius of the collapse is more nearly correct.

Though fractures exist in all the rocks penetrated by the core drilling (correlation diagram $A-A^{\prime}$ ), they are far more common in holes C-3 and C-5 nearest the Alice pit, and, in these drill holes, fractures increase in frequency downhole as the stratabound breccia is approached from above. Fracturing is even more intense within the rocks exposed in the pit itself, with the most intense fracturing centered around the usually water filled, lowest area in the south-center of the pit. In that area, only, there are rocks having fractures so closely spaced that the rocks are crackle breccia. There are no rocks exposed in the pit where fragments of the dolostone host rock are not fully clast supported.

Two major sets of fractures are obvious in the Alice pit. One is centripetal; it is parallel to the (rotated) bedding and thus dips inward toward the center of the pit. The second set is at high angles to the horizontal and includes fractures striking in several directions. The second set appears to be crudely radial from the pit center but may have one or more favored strike(s). Kidwell (1945) and McCracken (1971) emphasized high-angle fractures striking N. $80^{\circ}$ W. through the south-center of the pit. These fractures were called the Alice mine structure by McCracken (1971). This structural zone is easily visible in the present pit. It is a normal fault dipping $85^{\circ}$ to the south with about $2 \mathrm{ft}$ of vertical throw, downthrown on the south side. Its throw is only slightly greater than the throw on several other small, high-angle faults exposed in the present pit. It is indeterminate from our work whether the collapse pipe formed along this (or another) fault or whether the $\mathrm{N}$. $80^{\circ} \mathrm{W}$. fault is merely a local break along which some of the collapse occurred.

The dolostone blocks at the present pit exposure, and all other rocks cut in drilling to within just 1 or 2 $\mathrm{ft}$ from the top of the stratabound breccia, are mostly 
micron- to decimicron-crystalline. This is unlike the rocks of the stratabound breccia, which are recrystallized to medium to very coarse crystallinity.

Cross section B-B' at the Taylor prospect requires a vertical adjustment of the stratigraphy between drill-holes C-101 and C-104. We interpret an 8 -ft fault offset between the two drill holes, and judging from the distribution of sphalerite and hydrothermal pyrite-marcasite in correlation diagram B-B', we attribute possible genetic control of the Taylor prospect to that interpreted fault. Sphalerite and hydrothermal $\mathrm{FeS}_{2}$ are more abundant in the drill holes adjacent to the interpreted fault than in the drill holes farther away from it.

\section{HYDROTHERMAL MINERALIZATION}

The hydrothermal mineral system of the Ozark region can be defined to include only those sulfide minerals that have a close spatial association with several stages of saddle-shaped dolomite crystals having, at many places, a regular paragenetic sequence of colors: tan, then white, then limpid (clear), then pink. Pyrite, marcasite, and organic material that contain anomalously high amounts of $\mathrm{Cu}, \mathrm{Pb}, \mathrm{Zn}, \mathrm{Co}$, $\mathrm{Ni}, \mathrm{As}$, and $\mathrm{Ag}$ (Erickson and others, 1981) are visually separable from other pyrite and organic material by their interlayering with the saddle dolomite crusts. These metals-anomalous phases may contain as much as several hundred parts per million (ppm) each of arsenic, lead, and copper, and several tens of ppm each of cobalt and nickel. Several ppm silver are present locally. Pyrobitumen locally has thousands or even tens of thousand ppm molybdenum. Also, most metals-anomalous pyrite occurs as polyhedral crystals or is botryoidal in form rather than in simple cubic crystals. Another part of the hydrothermal-stage assemblage is dark-gray, very fine grained, sucrosic-textured, replacement silica (jasperoid) containing intercrystalline sulfides. Over a period of only a few years of storage, the metalsanomalous iron sulfides and organic material oxidize and alter, forming limonitic stains in the adjacent carbonate rock and locally forming melanterite efflorescences on the iron sulfides or pyrobitumens. Nonanomalous pyrite does not weather quickly in the core boxes. Applying these criteria, we logged hydrothermal mineralization separately from background diagenetic pyrite and were able to compare it with other Mississippi Valley-type mineralization in the region, which enabled us to determine whether or not Caulfield district mineralization was part of the recognizable regional system.

\section{SITES OF HYDROTHERMAL-STAGE MINERALS}

The drill holes on the correlation diagrams show occurrences of sphalerite and polyhedral, botryoidal, or jasperoid-hosted iron sulfides. Zinc grades are shown where an assay was run by Kerr-McGee Corporation on an interval of core.

There is a large variety of features in the cores that host hydrothermal-stage minerals, but without exception they fall into the collective category of secondary porosity. Any type of secondary porosity can host sphalerite and (or) hydrothermal iron sulfides and, locally, hydrothermal saddle dolomite, dickite, scalenohedral calcite, and, in one sample, a trace of galena. None of the open space in these Ordovician rocks is primary porosity.

Fractures are the most common type of secondary porosity that host hydrothermal-stage minerals. Most fractures are sharp walled and planar having a fraction of a millimeter to $2 \mathrm{~mm}$ of coarser crystalline dolomite as an alteration selvage against unaltered dolostone. Fracture and veinlet attitudes fall into two general groups relative to the bedding and core axis: low angle to parallel to bedding, and high angle, corresponding respectively to the sets of the Alice pit. Veinlet-rich zones account for the highest concentrations of metals found in the low-grade mineralized intervals of the eight drill holes (correlation diagrams $\mathrm{A}-\mathrm{A}^{\circ}$ and $\mathrm{B}-\mathrm{B}^{\circ}$ ).

Hydrothermal minerals also occur in vugs, and vug-prone rock types can contain bedding-parallel zones of sporadic zinc mineralization. Grainstone and boundstone (lithofacies "c" and "d," respectively) intervals are coarser grained and vuggy dolostone beds, such as brown ooidal chert and ghost-ooid-andalgal marker beds, that contain discontinuous lowgrade mineralization. Another type of vug, which commonly hosts trace hydrothermal mineralization, is the quartz geode, where hydrothermal minerals form crusts and druses atop quartz crystals.

Wall-rock replacement is an obviously minor process as evidenced in both the drill cores and the Alice mine. The only place where any significant volume of rock replacement occurred is in drill-hole C-3 within the stratabound breccia. There, a small mass of pyritic jasperoid was cut, and about 3 volumepercent hydrothermal pyrite-marcasite occurs as a partial replacement of the breccia matrix in the jasperoid. 


\section{PARAGENESIS}

The paragenetic sequence is mentioned here to add minerals not observed by Kidwell $(1945,1946)$, to provide evidence of the linkage of the Caulfield district to the regional hydrothermal system, and to report the following additional observation. The very dark, blue-black, layered-to-botryoidal sphalerite that constitutes the bulk of hypogene ore in the Alice mine is restricted to the Alice mine collapse pipe. Almost all sphalerite encountered in drill cores, even in drillhole $\mathrm{C}-3$, which is only $300 \mathrm{ft}$ from the zone of richest crackle breccia in the pit, is the later, clear, yellow- to bright-orange variety of sphalerite. Drill-hole C-3 is the only drill hole that has any trace of the blue-black, early sphalerite that constitutes the difference between ore and waste at the Alice mine. No trace of early sphalerite was found in Taylor prospect cores. On this basis alone, the economic potential of Caulfield district mineralization is probably limited to very small tonnage bodies and, thus, probably to only small-scale mining operations.

Figure 1 shows the sequence of hydrothermal minerals we observed, combining observations in the Alice pit with observations from drill core.

We identified several minerals in addition to those identified by Kidwell $(1945,1946)$. Dark organic matter (pyrobitumen?) (figure 1) rarely occurs within the selvages of recrystallized dolomite adjacent to some veinlets. It gives a petroliferous odor on grinding. Dickite is common as trace coatings on the earlier hydrothermal minerals in both vugs and veinlets in all cores we studied. Tan, geopetal decimicron-crystalline dolomite (1) locally forms a druse on the floors of small vugs; (2) forms very rare, isolated crystals of white saddle dolomite spar that form crusts in vugs or veinlets between the dark early sphalerite and latest yellow sphalerite; and (3) occurs as traces of limpid and pink saddle dolomite crystals forming a later crustification. These are the hydrothermal dolomite crusts recognized regionwide. They probably correspond, respectively, to late zone I (white), zones II and III (limpid), and zone IV (pink) of the cathodoluminescent dolomite microstratigraphy from Voss and Hagni (1985) and Rowan (1986). The tan, white, limpid, and pink hydrothermal dolomites tie the Caulfield mineralization firmly into the regional Ozark Mississippi Valley-type deposit system.

\section{DISCUSSION}

\section{ORIGIN OF BRECCIA AND RELATION TO OTHER DEPOSIT TYPES}

The geometry of breccia bodies and the thick, laminated internal sediment in stratabound breccia of the Caulfield district is similar to breccia formed by surficial karst processes (Choquette and James, 1988, p. 10). For example, a small circular collapse might, at one time, have reached a (now eroded) paleosurface as a sinkhole. At a later time, after moderate burial and mineralization, there may have been a "filled-sink" iron deposit above the present level in the collapse breccia. Filled-sink iron deposits occur within $10 \mathrm{mi}$ to the east in the West Plains district (Grawe, 1945). Alternatively, the overlying part of the collapse may have hosted a "circle" barite deposit like the McCanless mine, $46 \mathrm{mi}$ to the north in Texas County, which is also hosted by rocks of the Cotter or Jefferson City Dolomites (Wharton, 1987).

\section{GENETIC GEOCHEMISTRY CONSIDERATIONS}

It is likely that, at the Alice mine, metals and sulfur were carried in a single rising mineralizing solution. Beds $200 \mathrm{ft}$ laterally away from ore contain an average of less than 1 percent sulfur. These rocks change abruptly into the restricted pipelike ore body containing about 3 weight percent zinc in $\mathrm{ZnS}$ and about 2 volume percent $\mathrm{FeS}_{2}$, totalling about 5 weight percent sulfur and about 5 weight percent metals. Only an ore fluid carrying metals and sulfur together, with major flux upward through the pipe, makes sense in explaining this pattern of deposition.

Hypothetical processes carrying metals in one solution, up the pipe, to meet sulfur in a second solution of reasonable composition, either resident in pore water or permeating laterally, would need to resupply sulfur in the second solution. From the distribution of early, dark sphalerite, the metalstransporting solution of any mixing model must have moved principally within the pipe. Alternatives to the one-solution model include that a sulfur-rich mineral mass existed at the orebody site prior to mineralization. Neither pre-ore pyrite nor pre-ore sulfate minerals were present in the necessary 


\begin{tabular}{|c|c|c|c|}
\hline Time $\longrightarrow$ & Pre-ore & Hydrothermal stage & $\begin{array}{l}\text { Weathering } \\
\text { and residual } \\
\text { enrichment }\end{array}$ \\
\hline $\begin{array}{l}\text { Wall-rock dolostone } \\
\text { Quartz masses } \\
\text { Brecciation }\end{array}$ & & & \\
\hline $\begin{array}{l}\text { Intercrystalline wall-rock } \\
\text { pyrobitumen selvages } \\
\text { Sphalerite } \\
\text { Pyrite, marcasite, and } \\
\text { jasperoid } \\
\text { Thin quartz druses } \\
\text { Dolomite } \\
\text { Dickite } \\
\text { Calcite }\end{array}$ & CR & 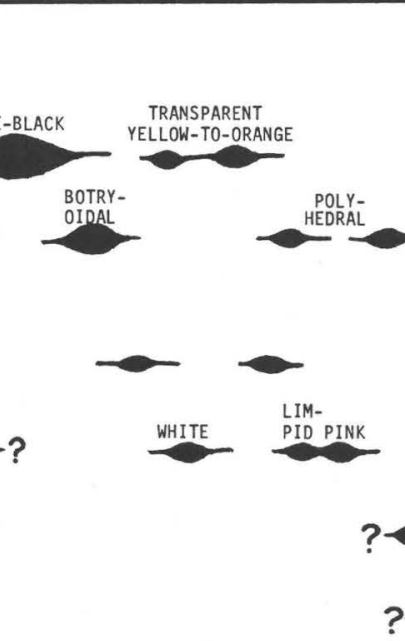 & \\
\hline $\begin{array}{l}\text { Smithsonite, hemimorphite, } \\
\text { goethite/limonite, and } \\
\text { melanterite }\end{array}$ & & & \\
\hline
\end{tabular}

Figure 1.-Paragenetic sequence observed in the Alice mine and in drill cores. 
amounts in the volume of rock now mineralized at the Alice mine. Wall-rock sulfur was not in the form of sulfate just prior to ore deposition. Anhydrite had earlier been leached or pseudomorphed by quartz, and there was everywhere a small amount of background diagenetic pyrite. Even if all the quartz masses and molds now in the host rock were at one time anhydrite, these wall rocks would never have contained more than 1 percent pre-ore sulfur.

There seems to be no hydrologic reason for a laterally recharging sulfur-bearing solution to meet the ascending metalliferous solution at this stratigraphic level. The Gunter Sandstone Member aquifer of the Gasconade Dolomite is down section as are the very porous, pervasively vuggy dolostone of the Gasconade Dolomite and the Eminence Dolomite. These stratigraphic intervals make sense as lateral aquifers, but the Cotter Dolomite does not. Lower Ordovician rocks up section have similar porosities to the Caulfield host rocks. Middle Ordovician through Upper Devonian rocks are not found across this part of the Ozark dome, and it is not known if they ever were present. Mississippian limestone up section is less porous than Caulfield's fine-grained host dolostone. Only the stratabound breccia makes sense as a lateral aquifer in this local setting. There is no reason to suspect that two separate and chemically distinct solutions could have been moving through these rocks under the necessarily different hydrologic controls at ore stage. With no sulfur resupply from the "second" solution we suspect the most straightforward hypothesis: sulfur and metals moving upward together in a single solution with a maximum flux through the zone of vertical permeability centered on the collapse breccia pipe.

Ore solution sulfur probably was sulfide rather than sulfate. Otherwise, a reductant for the sulfur would be required, and only organic carbon and (or) $\mathrm{Fe}^{2+}$ in the rocks or in solution are probable reductants in this type of sedimentary setting. Insufficient host-rock supply and lack of secondsolution . resupply apply to either one or the combination of these two reductants.

The stratabound breccia is the one reasonable choice for a laterally recharging aquifer in any mixing model, but our observations determined that this breccia was healed, recrystallized, and vugs formed prior to ore-stage tan dolomite deposition on the floors of vugs. By ore stage the stratabound breccia was probably no vuggier than several other beds (see porosity logs on correlation diagrams $A-A^{\prime}$ and B-B $^{\prime}$ ). However, breccia-healing, recrystallization, vug formation, and geopetal tan dolomite deposition could have been part of a continuous, early ore-stage sequence. The petrography and detailed fluid inclusion and isotope geochemistry of the stratabound breccia should be studied to test this mixing scenario and also to determine the origin of the brecciation.

Because of its small size and dramatic lateral change in the amounts of metals and sulfur, the Alice mine Mississippi Valley-type deposit appears to accommodate only the hypothesis of single-solution co-transport of zinc and reduced sulfur. That geochemical hypothesis was demonstrated feasible by Sverjensky (1984). Further work should be designed to test the one-solution model at the Alice mine.

\section{CONCLUSIONS}

\section{CAULFIELD DISTRICT GEOLOGY}

Host rock of the Caulfield district is dolostone of the Lower Ordovician Cotter Dolomite that was deposited in low energy peritidal environments as cyclic shallowing-upward sequences. Each shallowingupward sequence was deposited by a transgressiveregressive cycle. Progradation and island-coalescence of a mudbank system similar to modern Florida Bay account for most of the sediment thickness. Details within individual cycles change from place to place, but, using the combination of distinctive chert-bearing rock types and cycle recognition, bed-for-bed correlation is simple across distances of at least $6 \mathrm{mi}$, which is nearly inclusive of the entire Caulfield district from its center. Cycle-for-cycle correlation of the Lower Ordovician rocks across all of southern Missouri may be possible if correlation can be conducted in the same detail as was done in this study.

Throughout the Caulfield district, a variety of types of secondary porosity are the principal control for deposition of sphalerite and other hydrothermal minerals. Grainstone and boundstone parts of each shallowing-upward sequence are generally more vuggy than overlying and underlying rocks. The grainstoneboundstone intervals form discontinuously mineralized bed-parallel zones of low-grade mineralization of no economic potential. The economically important type of secondary porosity in the district is fracturing. For example, the Alice mine, largest zinc producer of the district, is hosted by a vertical, cylindrical pipe of collapse crackle-breccia grading out radially into fracture stockworks. Crackle-breccia and fracture open space were partially filled by sphalerite. 
At the Alice mine, grades of zinc in excess of 3 weight percent are restricted to the central part of the zone of collapsed bedding. In total, the zone of collapse is about $275 \mathrm{ft}$ in diameter. The average grade is 3 percent zinc or more only within a $120-\mathrm{ft}$ diameter, near-vertical, cylindrical rock mass centered in the east-center of the open pit (according to polygon-method grade-tonnage calculation from the combination of holes reported by Needham and Kreamalmyer (1947) and the Kerr-McGee Corporation drill holes). Veinlike zones of crackle breccia extend outward locally from the cylindrical rock mass along the radial(?) and centripetal fracture systems, producing, for example, a stockwork of mostly bed-parallel (centripetal) sphalerite veinlets that yielded three intercepts of over 1 percent zinc in drill-hole C-3 (correlation diagram A-A'). Rock containing 3 percent zinc or more is approximately coincident with rock within which the early blue-black sphalerite occurs as breccia fracture fill. The later, volumetrically minor, clear, yellow to orange sphalerite is found as minor and trace mineralization throughout all of the rocks studied.

Alice mine bedding collapse breccia may be rooted in a stratabound body of rehealed and coarsely recrystallized dolostone breccia. This stratabound breccia underlies all or part of the rocks between the Alice mine and the Taylor prospect. Both the stratabound and the collapse brecciation occurred prior to ore deposition, as apparently did the rehealing of the stratabound breccia. The stratabound breccia was probably recrystallized to medium- and coarse-grain sizes before ore deposition, but this tentative conclusion merits further petrographic and geochemical testing. The stratabound breccia is cut by veinlets of clear sphalerite and pink dolomite, and tan dolomite is in vugs. Tan dolomite deposition, recrystallization, and vug formation could be overlapping events early in the ore stage.

\section{ECONOMIC POTENTIAL}

The economic potential of the Caulfield district, with the Alice mine and the Taylor prospect as models, is very limited. However, the simple geology, including simply shaped ore bodies, easy recognition of the blue-black sphalerite ore, and probably cheap concentration by a gravity or magnetic method might actually make a small, one- or two-man, highly selective mine possible even at today's prices. For example, the 120 - $\mathrm{ft}$ diameter cylindrical rock mass grading about 3 percent zinc is essentially proven to a depth of $65-120 \mathrm{ft}$ below the bottom of the Alice pit.
Continuity of the structural controls of Alice mine mineralization is demonstrated by the Kerr-McGee Corporation drilling (this study) to depths of about $300 \mathrm{ft}$ below the pit bottom, and the same diameter of pipe can be reasonably inferred to be similarly mineralized to a depth of at least $250 \mathrm{ft}$. There may be a crude vertical mineral zonation with sphalerite decreasing and pyrite increasing downward (correlation diagrams $A-A^{\prime}$ and $B^{-} B^{\prime}$ ). Using the average density from four hand samples of the blueblack sphalerite-mineralized crackle breccia, this volume of rock has an inferred reserve of 260,000 short tons of rock containing 3 percent zinc. Value of the end-product zinc in this rock body would be $\$ 7.86$ million at an estimated 90 percent recovery (at New York zinc spot metal price of $56 \notin / \mathrm{lb}$ as of $1 / 3 / 92$ ). Profitability of mining would depend on (1) cost and efficiency of mining and (presumably on-site) sphalerite concentration, (2) cost of truck haulage of the concentrate to a smelter probably in the southeast Missouri district, and (3) custom smelting cost notably including the presence or absence of any penalty or bonus metal such as cadmium or silver, respectively.

\section{RECOMMENDATIONS FOR EXPLORATION}

Exploration for additional deposits of the size and type at the Alice mine could not involve any expensive modern method-the target is too small. The Alice mine ore body geometry and surficial expression is similar to that described for filled sink iron deposits, and we recommend that the methods suggested for exploration for iron deposits by Grawe $(1945$, p. 85 86) be adopted by anyone searching for additional deposits similar to the Alice mine. We recommend panning of the soils for smithsonite (dry bone) as an additional exploration method, and we recommend close-spaced gravity surveying to define the extent of well-mineralized rock bodies. Only an outcropping or near-surface ore body has any chance to be profitably mined at the expected size and grade.

\section{REFERENCES CITED}

Bohm, R.A., 1981, Structural map of Missouri contoured on the top of the Eminence Dolomite: Missouri Division of Geology and Land Survey OFM-81-12-GI, scale 1:1,000,000.

Choquette, P.W., and James, N.P., 1988, Introduction, in James, N.P., and Choquette, P.W., eds., Paleokarst: New York, Springer-Verlag, p. 1-21. 
Crawford, Johnson, and Hoagland, A.D., 1968, The Mascot-Jefferson City zinc district, Tennessee, in Ridge, J.D., ed., Ore deposits of the United States: New York, AIME, p. 242-256.

Dickson, J.A.D., 1966, Carbonate identification and genesis as revealed by staining: Journal of Sedimentary Petrology, v. 36, p. 491-505.

Dunham, R.J., 1960, Classification of carbonate rocks according to depositional texture: American Association of Petroleum Geologists Memoir 1, p. 108-121.

Enos, P., and Perkins, R.D., 1979, Evolution of Florida Bay from island stratigraphy: Geological Society of America Bulletin, v. 90, p. 59-83.

Erickson, R.L., Chazin, Barbara, and Erickson, M.S., 1989, Summary geochemical maps of the Harrison $1^{\circ} \times 2^{\circ}$ quadrangle, Arkansas and Missouri: U.S. Geological Survey Miscellaneous Field Studies Map MF-1994-A, scale 1:250,000 and 1:500,000.

Erickson, R.L., Mosier, E.L., Odland, S.K., and Erickson, M.S., 1981, A favorable belt for possible discovery in subsurface Cambrian rocks in Southern Missouri: Economic Geology, v. 76, p. 921-933.

Fischer, A.G., 1964, The Lofer cyclothems of the Alpine Triassic, in Merriam, D.F., ed., Symposium on cyclic sedimentation: State Geological Survey of Kansas Bulletin 169, v. 1, p. 107-149.

Folk, R.L., and Pittman, J.S., 1971, Length slow chalcedony: A new testament for vanished evaporites: Journal of Sedimentary Petrology, v. 41, p. 1045-1058.

Friedman, G.M., 1965, Terminology of crystallization textures and fabrics in sedimentary rocks: Journal of Sedimentary Petrology, v. 35, p. 643655.

Gerdemann, P.E., and Myers, H.E., 1972, Relationships of carbonate facies patterns to ore distribution and to ore genesis in the Southeast Missouri lead district: Economic Geology, v. 67, p. 426-433.

Grawe, O.R., 1945, Pyrite deposits of Missouri: Missouri Division of Geology and Land Survey, v. $\mathrm{XXX}$, 2d series, $482 \mathrm{p}$.

Grohskopf, J.G., and McCracken, Earl, 1949, Insoluble residues of some Paleozoic formations in Missouri, their preparation, characteristics, and applications: Missouri Division of Geology and Land Survey, Report of Investigations 10, 39 p.

Hagan, G.M., and Logan, B.W., 1974, Development of carbonate banks and hypersaline basins, Shark Bay, Western Australia, in Logan, B.W., Read,
J.F., Hagan, G.M., Hoffman, P., Brown, R.G., Wood, P.J., and Gebelein, C.D., Evolution and diagenesis of Quaternary carbonate sequences, Shark Bay, Western Australia: American Association of Petroleum Geologists Memoir 22, p. 61-139.

Hardie, L.A., 1977, ed., Sedimentation on the modern carbonate tidal flats of northwest Andros Island, Bahamas: Baltimore, Johns Hopkins University Press, 202 p.

Hardie, L.A., and Ginsburg, R.N., 1977, Layering: The origin and environmental significance of lamination and thin bedding, in Hardie, L.A., ed., Sedimentation on the modern carbonate tidal flats of northwest Andros Island, Bahamas: Baltimore, Johns Hopkins University Press, p. 50-123.

Ingram, R.L., 1954, Terminology for the thickness of stratification and parting units in sedimentary rocks: Geological Society of America Bulletin, v. 65 , p. 937-938.

James, N.P., 1979, Shallowing-upward sequences in carbonates, in Walker, R.G., ed., Facies Models: Geoscience Canada Reprint Series 1, p. 109-119.

Kidwell, A.L., 1945, Geology of the Alice mine: unpublished Missouri Division of Geology and Land Survey Report MR-25023, 30 p.

1946, The Alice mine of southern Missouri: Rocks and Minerals, October 1946, p. 666-667.

Kyle, J.R., 1976, Brecciation, alteration, and mineralization in the Central Tennessee Zinc District: Economic Geology, v. 71, p. 892-903.

Laporte, L.F., 1967, Carbonate deposition near mean sea level and resultant facies mosaic: Manlius Formation (Lower Devonian) of New York state: American Association of Petroleum Geologists Bulletin, v. 51, p. 73-101.

Leach, D.L., and Rowan, E.L., 1986, Genetic link between Ouachita fold belt tectonism and the Mississippi Valley-type lead-zinc deposits of the Ozarks: Geology, v. 14, p. 931-935.

Logan, B.W., Hoffman, P., and Gebelein, C.D., 1974, Algal mats, cryptalgal fabrics, and structures, Hamelin Pool, Western Australia, in Logan, B.W., Read, J.F., Hagan, G.M., Hoffman, P., Brown, R.G., Woods, P.J., and Gebelein, C.D., Evolution and diagenesis of quaternary carbonate sequences, Shark Bay, Western Australia: American Association of Petroleum Geologists Memoir 22, p. 140-194.

McCafferty, A.E., Cordell, Lindrith, and Bracken, R.E., 1989, Geophysical maps and interpretation of basement terrane in the Harrison $1^{\circ} \times 2^{\circ}$ quadrangle, Missouri and Arkansas: U.S. 
Geological Survey Miscellaneous Field Studies Map MF-1994-B, scale 1:250,000.

McCracken, Earl, and McCracken, M.H., 1964, Subsurface maps of the Lower Ordovician (Canadian Series) of Missouri: Missouri Division of Geology and Land Survey, Rolla, Missouri, scale $1: 1,000,000$.

McCracken, M.H., 1971, Structural features of Missouri: Missouri Division of Geology and Land Surveys Report of Investigations 49, Rolla, Missouri, 100 p.

Milliken, K.L., 1979, The silicified evaporite syndrome; two aspects of silicification history of former evaporite nodules from southern Kentucky and northern Tennessee: Journal of Sedimentary Petrology, v. 49, p. 245-256.

Needham, A.B., and Kreamalmyer, K.L., 1947, Alice mine, Ozark County, Missouri: U.S. Bureau of Mines Report of Investigations 4056, 16 p.

Purser, B.H., and Evans, G., 1973, Regional (carbonate) sedimentation along the Trucial Coast, SE Persian Gulf, in Purser, B.H., ed., The Persian Gulf: New York, Springer-Verlag, p. 211231.

Reineck, H.E., and Singh, I.B., 1975, Depositional sedimentary environments: New York, SpringerVerlag, 439 p.

Rhodes, D., Lantos, E.A., Webb, R.J., and Owens, D.C., 1984, Pine Point ore bodies and their relationship to stratigraphy, structure, dolomitization, and karstification of the Middle Devonian barrier complex: Economic Geology, v. 79, p. 991-1054.

Rowan, E.L., 1986, Cathodoluminescent zonation in hydrothermal dolomite cements-Relationship to Mississippi Valley-type lead-zinc mineralization in southern Missouri and northern Arkansas, in Hagni, R.D., ed., Process mineralogy VI, American Institute of Mining, Metallurgical, and
Petroleum Engineers: Warrendale, Penn., The Metallurgical Society, p. 69-87.

Shinn, E.A., 1983, Tidal flat, in Scholle, P.A., Bebout, D.G., and Moore, C.H., eds., Carbonate depositional environments: American Association of Petroleum Geologists Memoir 33, p. 171-210.

Skall, H., 1975, The paleoenvironment of the Pine Point lead-zinc district: Economic Geology, v. 70, p. 22-47.

Snyder, F.G., and Gerdemann, P.E., 1968, Geology of the Southeast Missouri lead district, in Ridge, J.D., ed., Ore deposits of the United States: New York, AIME, p. 326-358.

Sverjensky, D.A., 1984, Oil field brines as ore-forming solutions: Economic Geology, v. 79, p. 23-37.

Voss, R.L., and Hagni, R.D., 1985, The application of cathodoluminescence microscopy to the study of sparry dolomite from the Viburnum Trend, southeast Missouri, in Hausen, D.M., and Kopp, O., eds., Proceedings, Mineralogy-Applications to the Minerals Industry (Paul F. Kerr Memorial Symposium): New York, AIME, p. 51-68.

Walther, J., 1894, Einleitung in die geologie als historiche wissenschaft-Lithogenesis der Gegenwart [Introduction to geology as a historical science-Lithogenesis of the present]: Jena, Fischer Verlag, Bd. 3, p. 535-1055. (as translated by Blatt, H., Middleton, G.V., and Murray, R.C., 1972, Origin of sedimentary rocks: New Jersey, Prentice Hall, p. 187-188.)

Wentworth, C.K., 1922, A scale of grade and class terms for clastic sediments: Journal of Geology, v. 30 , p. 377-392.

Wharton, H.M., 1987, Mines, prospects, and occurrences of metallic minerals and barite, Springfield $1^{\circ} \times 2^{\circ}$ quadrangle, Missouri: U.S. Geological Survey Miscellaneous Field Studies Map MF-1830-C, scale 1:250,000. 